\title{
Sufentanil and Midazolam Dosing and Pharmacogenetic Factors in Pediatric Analgosedation and Withdrawal Syndrome
}

\author{
K. HRONOVÁ ${ }^{1}$, P. POKORNÁ ${ }^{1,2,3}$, L. POSCH ${ }^{2}$, O. SLANA $\check{R}^{1}$ \\ ${ }^{1}$ Institute of Pharmacology, First Faculty of Medicine, Charles University, Prague, Czech Republic, \\ ${ }^{2}$ Clinic of Pediatric and Adolescent Medicine, General University Hospital, Prague, Czech \\ Republic, ${ }^{3}$ Intensive Care and Department of Pediatric Surgery, Erasmus MC - Sophia Children's \\ Hospital, Rotterdam, Netherlands
}

Received September 1, 2016

Accepted October 21, 2016

\section{Summary}

Our aim was to describe the effect of dosing and genetic factors on sufentanil- and midazolam-induced analgosedation and withdrawal syndrome (WS) in pediatric population. Analgosedation and withdrawal syndrome development were monitored using COMFORT-neo/-B scores and SOS score. Length of therapy, dosing of sufentanil and midazolam were recorded. Genotypes of selected candidate polymorphisms in CYP3A5, COMT, $A B C B 1, O P R M 1$ and $P X R$ were analysed. In the group of 30 neonates and 18 children, longer treatment duration with midazolam of $141 \mathrm{~h}(2-625)$ vs. $88 \mathrm{~h}(7-232)$ and sufentanil of $326.5 \mathrm{~h}(136-885)$ vs. $92 \mathrm{~h}(22-211)$ (median; range) was found in the patients suffering from WS vs. non-WS group, respectively. Median midazolam cumulative doses were in the respective values of $18.22 \mathrm{mg} / \mathrm{kg}(6.93-51.25) \mathrm{vs} .9 .94 \mathrm{mg} / \mathrm{kg}$ (2.12-49.83); $P=0.03$, and the respective values for sufentanil were $\quad 88.60 \mu \mathrm{g} / \mathrm{kg} \quad(20.21-918.52) \quad$ vs. $\quad 21.71 \mu \mathrm{g} / \mathrm{kg}$ (4.5-162.29); $P<0.01$. Cut off value of 177 hours for sufentanil treatment duration represented predictive factor for WS development with $81 \%$ sensitivity and $94 \%$ specificity. SNPs in the candidate genes COMT, PXR and $A B C B 1$ affected the dosing of analgosedative drugs, but were not associated with depth of analgosedation or WS. Cumulative dose and length of analgosedative therapy with sufentanil significantly increases the risk of WS in critically ill neonates and children.

\section{Key words}

Analgosedation • Withdrawal • Sufentanil • Midazolam

\section{Corresponding author}

K. Hronová, Institute of Pharmacology, First Faculty of Medicine,
Charles University, Albertov 4, 12800 Prague, Czech Republic. E-mail: karolina.hronova@lf1.cuni.cz

\section{Introduction}

Sufentanil is a strong sedative opioid indicated for analgosedation monotherapy in ventilated patients. Sufentanil administration may be accompanied by known opioid-related adverse effects-nausea, vomiting, respiratory depression, constipation and withdrawal syndrome (Schug et al. 1992). Clinical effect is mediated by polymorphic $\mu$-opioid receptor 1 (OPRM1). Variant of the major OPRM1 nonsynonymous SNP $118 A>G$ (rs 1799971) decreased efficiency of G-protein coupling to $58 \%$ in comparison with wt homozygotes (Oertel et al. 2009). The clinical relevance of this SNP for the sufentanil treatment in pediatric population has been indicated by Mamie et al. (2013), who described higher Faces Pain Scale (FPS) scores across the 24 postoperative hours in heterozygotes compared with wt homozygotes. In another study, infants $(n=140)$ carrying variant allele suffered from shorter duration of neonatal abstinence syndrome (NAS) and were less likely to receive any treatment than wt homozygotes (Wachman et al. 2013).

Catechol-O-methyl transferase (COMT) plays a central role in the degradation of extracellular dopamine and norepinephrine in the CNS. Variant allele homozygotes for the SNP COMTrs4680 had enzymatic activity decreased by $38 \%$ compared to wild-type homozygotes in post mortem collected brain samples (Chen et al. 2004, Lachman et al. 1996). Higher levels of 
dopamine in COMTrs4680 SNP carriers were associated with lower levels of enkephalins, leading to down regulation of $\mu$-opioid receptor (Zubieta et al. 2003). Wild-type homozygous children had significantly higher sufentanil-induced analgesia after orthopedic or abdominal surgery (Mamie et al. 2013). Variant allele carriers stayed shorter time in the hospital and the treatment with 2 or more medications was used less frequently than in wild-type homozygous neonates with NAS (18\% vs. $56 \%$ ), (Wachman et al. 2013).

Midazolam is another drug used for analgosedation in pediatric and neonatal intensive care units (Anderson and Larsson 2011). Midazolam is metabolized in the liver via CYP3A (Wong et al. 2004) and the clinical effects of midazolam are prolonged in neonates due to immature cytochrome P450 enzymes. Polymorphisms in CYP3A as well as in nuclear receptors regulating its transcription potentially influence midazolam effects (De Jonge et al. 2015, Oleson et al. 2010, Seng et al. 2014). The effect of the common polymorphism $C Y P 3 A 5 * 3$ is unclear, as the results of the studies are contradictory (Shih and Huang 2002, Wong et al. 2004). Further, in CYP3A5 non-expressers, some role of $C Y P 3 A 4 * 22$ polymorphism on midazolam clearance has been observed in allograft recipients, but this SNP has a very low allele frequency in Caucasian population (De Jonge et al. 2015).

Midazolam is a substrate of efflux transporter ABCB1 that could affect the distribution of the drug in the body and subsequently also alter its efficacy (TolleSander et al. 2003).

Patients at pediatric intensive care units suffer frequently from iatrogenic withdrawal syndrome (WS) related to opioid and/or benzodiazepine that develops in up to $57 \%$ children (Katz et al. 1994). Traditionally fentanyl is used as first-line opioid (66\%) and midazolam as the first-line benzodiazepine ( $86 \%)$ for analgosedation at PICU. The WS was dependent on the length and total exposure to fentanyl and midazolam with the incidence increasing after 5 days of continuous infusion or when round-the-clock administration schedule was used (Arnold et al. 1990, Dominguez et al. 2003, French and Nocera 1994, Grant et al. 2013, Katz et al. 1994).

The aim of our study was to describe the impact of candidate gene polymorphisms on sufentanil- and midazolam- induced analgosedation and/or WS. Another aim of our study was to describe the relation between sufentanil dosing or treatment duration and development of WS.

\section{Methods}

Mechanically ventilated full-term neonates and children at the Pediatric Intensive Care and Resuscitation Unit of the General Faculty Hospital in Prague were prospectively recruited into the study after obtaining informed consent from their legal representatives from January 2010 to September 2013. The study was approved by the Ethics Committee of the General Faculty Hospital in Prague and it was conducted in accordance with the Declaration of Helsinki.

Inclusion criteria encompassed neonates $\geq 36$ gestational weeks and children $\geq 3$ months to 18 years of age, with length of continuous intravenous infusion of sufentanil and/or midazolam $\geq 48 \mathrm{~h}$. Neonates and children with severe hepatic impairment and acute renal failure were excluded. Subjects were treated according to PICU sedation recommendation (Poh et al. 2014).

Postmenstrual age (PMA), weight/birth weight, sex, ethnicity, main and secondary diagnoses were recorded for all subjects, while the Apgar score, way of delivery (spontaneous/Caesarian section) were registered for neonates only.

Organ functions were evaluated using Goldstein score for cardiovascular, respiratory, neurological, hematological and hepatic dysfunction (Goldstein et al. 2005). Renal functions were recorded according to pRIFLE criteria (Akcan-Arikan et al. 2007). Length of therapy (h) and cumulative dose of tramadol ( $\mathrm{mg} / \mathrm{g}$ ) were recorded as the median (range). Concomitant therapy, length of PICU and overall hospital stay were also registered.

Validated COMFORT-B and COMFORT-NEO scale was used for monitoring of analgosedative effects. COMFORT score of $<11$ was considered indicative of oversedation, COMFORT score of $>22$ for insufficient sedation (Van Dijk et al. 2000, Van Dijk et al. 2009). Symptoms of withdrawal syndrome were systematically evaluated after fifth day of stay at PICU. The Sophia Observational Scale (SOS) was used for WS assessment. The total score was noted every $3 \mathrm{~h}$, with the count equal or more than 4 for two consecutive measurements indicative for WS occurrence (Ista et al. 2013, Ista et al. 2009, Ista et al. 2009). Both SOS and COMFORT score were systematically registered by trained personnel (linear weighted kappa median 0.80), (Pokorná et al. 2016).

Samples of peripheral venous blood for DNA isolation were collected in tubes containing EDTA and 
immediately frozen and stored at $-20^{\circ} \mathrm{C}$ until further processing. Genomic DNA was extracted from blood leukocytes using QIAamp DNA Blood Mini Kit (Quiagen Ltd.). Detection of the candidate gene polymorphisms in COMT (rs4633, rs4680, rs4818) ABCB1 G2677T/A (rs2032582), ABCB1 C3435T (rs1045642), OPRM1A118G (rs1799971) and PXR $10799 G / A, P X R-25385 C / T, P X R-24113 C / T, P X R$ $7635 \mathrm{~A} / G \quad(r s 1054191, \quad r s 3814055, \quad r s 2276706$, rs6785049) was performed as published previously (Bartosova et al. 2015, Buzkova et al. 2008, George et al. 2008, Pechandova et al. 2006, Polívková 2006, Redden et al. 2005, Van Schaik et al. 2002).

Mann-Whitney test was used for between group median comparison of cumulative doses, doses per $\mathrm{kg}$ and hour and the length of therapy. Chi-square test was used for categorical variables. A $P$-value of less than 0.05 was considered statistically significant. In order to explain the development of WS, a multivariate logistic regression model was used with the total dose of sufentanil, total dose of midazolam, duration of sufentanil treatment and duration of midazolam treatment as explanatory variables in subgroups of neonates and children over 3 months of age, who received both drugs concomitantly. Logistic regression analysis was carried out with Wald forward stepwise method, $P$ for inclusion and exclusion of a parameter was set to 0.05 and 0.15 , respectively. The ROC curve analysis was performed to identify the value offering the best sensitivity and specificity. The statistical package Dell STATISTICA version 12 was used.

\section{Results}

\section{Baseline characteristics}

Baseline characteristic parameters of neonates and children are summarized in Table 1. Twenty-five neonates were admitted with respiratory failure (due to perinatal asphyxia, RSV pneumonia, or aspiration of amniotic fluid), 4 neonates with sepsis and one with meningoencephalitis. Totally 24 neonates were discharged with no or minor health disturbance, 2 were transferred to another department, 2 patients were discharged with moderate/severe health disturbance and 2 died. Seven children were admitted with pneumonia/respiratory failure, 5 children suffered from burns, 2 from myocarditis, 2 from brain atrophy, one form sepsis and dehydration. Seven children were discharged with no or minor consequences, 10 were transferred to another department and one child died. Table 2 presents observed allelic frequencies in the whole study population. Except sufentanil and midazolam, the patients received median (range) of $0.25 \mathrm{mg} / \mathrm{kg} / \mathrm{h}$ $(0.03-0.34 \mathrm{mg} / \mathrm{kg} / \mathrm{h})$ hourly dose i.e. median (range) of $6.0 \mathrm{mg} / \mathrm{kg} /$ day $(0.72-8.16 \mathrm{mg} / \mathrm{kg} /$ day $) \quad$ of tramadol (13 neonates, 14 children) and median (range) of $0.24 \mathrm{mg} / \mathrm{kg} / \mathrm{h}(0.03-1.06)$ of hourly dose i.e. median (range) of $5.76 \mathrm{mg} / \mathrm{kg} /$ day $\quad(0.72-25.4 \mathrm{mg} / \mathrm{kg} /$ day divided in two or three doses) of phenobarbital ( 28 neonates, 15 children). Some subjects received also clonidine ( 2 neonate and 6 children), ketamine ( 5 children) or chloralhydrate ( 4 children).

Table 1. Baseline characteristic parameters of neonates and children, F-female, M-male, n-number, PMA-postmenstrual age.

\begin{tabular}{|c|c|c|}
\hline Parameter & Neonates $(\mathbf{N}=\mathbf{3 0})$ & Children $(\mathrm{N}=18)$ \\
\hline $\operatorname{Sex}(M / F)$ & $17 / 13$ & $13 / 5$ \\
\hline PMA (weeks), median (range) & $40(37-42)$ & $124(48-730)$ \\
\hline Weight (kg), median (range) & $3.37(2.45-4)$ & $12(3.4-50)$ \\
\hline Apgar score $1^{\text {st }}$ min, median (range) & $4.5(0-10)$ & - \\
\hline Apgar score $5^{\text {th }}$ min, median (range) & $7(1-10)$ & - \\
\hline Apgar score $10^{\text {th }}$ min, median (range) & $8(3-10)$ & - \\
\hline Spontaneous labor $(n / N)$ & $13 / 30$ & - \\
\hline
\end{tabular}

Analgosedative therapy, COMFORT score, SOS score

Neonates received sufentanil for significantly shorter period than children while their median cumulative sufentanil dose was numerically lower, although not reaching the level of significance $(P=0.11)$. No significant difference was found between neonates and children with respect to dosing and duration of midazolam therapy (Table 3 ). Hourly dose of sufentanil 
Table 2. Allelic frequencies in the study population.

\begin{tabular}{lccc}
\hline Gene & SNP & RS number & $\begin{array}{c}\text { Observed variant } \\
\text { allele frequency }\end{array}$ \\
\hline CYP3A5 & $C 27289 A\left(C Y P 3 A 5^{*} 2\right)$ & $r s 28365083$ & 0.00 \\
OPRM1 & $A \underline{6986 G}\left(C Y P 3 A 5^{*} 3\right)$ & $r s 776746$ & 0.95 \\
$A B C B 1$ & $A 118 G$ & $r s 1799971$ & 0.11 \\
$A B C B 1$ & $C 3435 T$ & $r s 1045642$ & 0.50 \\
$P X R$ & $G 2677 T / A$ & $r s 2032582$ & 0.45 \\
$P X R$ & $G 10799 A$ & $r s 1054191$ & 0.15 \\
$P X R$ & $C-25385 T$ & $r s 3814055$ & 0.37 \\
$P X R$ & $C-24113 T$ & $r s 2276706$ & 0.37 \\
$C O M T$ & $A 7635 G$ & $r s 6785049$ & 0.66 \\
$C O M T$ & $C 186 T$ & $r s 4633$ & 0.49 \\
\hline
\end{tabular}

Table 3. Analgosedative therapy in neonates and children, MDZ-midazolam, values in media (range), ${ }^{*} P<0.05 v s$. children.

\begin{tabular}{lcc}
\hline AS drug & Neonates $(\mathbf{N}=\mathbf{3 0})$ & Children (N=18) \\
\hline Patients on sufentanil & $26 / 30$ & $17 / 18$ \\
Patients on MDZ & $23 / 30$ & $14 / 18$ \\
Cumulative sufentanil dose $(\mu \mathrm{g} / \mathrm{kg})$ & $28.23(5.10-280.40)$ & $63.44(4.50-918.52)$ \\
Cumulative $M D Z$ dose $(\mathrm{mg} / \mathrm{kg})$ & $12.63(212-51.25)$ & $12.47(2.83-41.36)$ \\
Duration of sufentanil perf. $(\mathrm{h})$ & $109(55-790)^{*}$ & $182(22-885)$ \\
Duration of $M D Z$ perf. $(\mathrm{h})$ & $105(7-625)$ & $111(2-398)$ \\
Sufentanil dose $\mu \mathrm{g} / \mathrm{kg} / \mathrm{h}$ & $0.24(0.07-1.96)$ & $0.35(0.10-1.04)$ \\
MDZ dose $\mathrm{mg} / \mathrm{kg} / \mathrm{h}$ & $0.11(0.05-0.35)$ & $0.14(0.07-0.29)$ \\
\hline
\end{tabular}

Table 4. COMFORT and SOS score values in neonates and children, values in median (range), ${ }^{*} P<0.05$ vs. children.

\begin{tabular}{lcc}
\hline Scale evaluation & Neonates $(\mathbf{N}=\mathbf{3 0})$ & Children (N=18) \\
\hline SOS score & $1(0-17)^{*}$ & $2(0-12)$ \\
COMFORT NEO/B score & $11(2-26)$ & $16(5-31)$ \\
COMFORT NEO/B $>22 / n$ & $2 / 2278$ & $99 / 2008$ \\
COMFORT $N E O / B<1 / / n$ & $1117 / 2278$ & $46 / 2008$ \\
\hline
\end{tabular}

was also similar in both populations.

Higher SOS score values were observed in the subgroup of children. COMFORT score $<11$ was registered in almost half of the neonates, whereas oversedation was relatively rare in children over 3 months. On the contrary, only exceptionally COMFORT score over 22 was registered in neonates (Table 4).
Genetic polymorphisms

Wild-type allele carriers in COMTrs4680 received significantly higher hourly dose of sufentanil $[(0.25 \mu \mathrm{g} / \mathrm{kg} / \mathrm{h}(0.07-1.18)]$, than variant homozygotes $[(0.15 \mu \mathrm{g} / \mathrm{kg} / \mathrm{h} \quad(0.10-0.23) ; \quad P=0.04]$. There was a numerical trend towards higher hourly dose of sufentanil in PXRA7635G wt allele carriers $[0.33 \mu \mathrm{g} / \mathrm{kg} / \mathrm{h}$ $(0.23-0.45)]$ compared with variant allele carriers 
$[0.21 \mu \mathrm{g} / \mathrm{kg} / \mathrm{h}(0.07-1.18) ; P=0.10]$.

A trend towards significance was observed in midazolam dosing in $A B C B 1 C 3435 T$ both wild-type allele carriers $[C C+C T, 0.10 \mathrm{mg} / \mathrm{kg} / \mathrm{h}(0.05-0.29)]$ and $C C$ carriers $[0.10 \mathrm{mg} / \mathrm{kg} / \mathrm{h}(0.05-0.20)]$ and variant allele homozygotes $[0.13(0.08-0.35) ; P=0.09, P=0.10$, respectively].

No association was observed between the candidate gene polymorphisms and COMFORT score values.
Withdrawal syndrome (WS)

Overall, 16 subjects developed withdrawal syndrome, 7 neonates and 9 children. All WS subjects received sufentanil. Significantly more analgosedative drugs per patient were used in the subjects, who suffered from WS compared with non-WS group. The analgosedative therapy, artificial ventilation and hospital stay were also significantly longer in the WS patients (Table 5).

Table 5. Results of therapy according to withdrawal syndrome. AS-analgosedation, AV-artificial ventilation, MDZ-midazolam, perf.perfusion, values in median, range, ${ }^{*} P<0.05 \mathrm{vs}$. WS group, ${ }^{* *} P<0.001 \mathrm{vs}$. WS group.

\begin{tabular}{|c|c|c|}
\hline Parameter & WS group $(\mathrm{N}=16)$ & Non-WS group $(\mathrm{N}=32)$ \\
\hline Both sufentanil and $M D Z(n / N)$ & $15 / 16$ & $20 / 32$ \\
\hline Only sufentanil $(n / N)$ & $1 / 16$ & $7 / 32$ \\
\hline Only $\operatorname{MDZ}(n / N)$ & $0 / 16$ & $5 / 32$ \\
\hline AS drug (n/patient) & $4(2-7)$ & $3(1-4)^{* *}$ \\
\hline Days of AS therapy & $21(9-60)$ & $6(2-13)^{* *}$ \\
\hline Days of $A V$ & $13.5(7-81)$ & $5(3-12)^{* *}$ \\
\hline Days of hospitalization & $24(10-81)$ & $13(3-29)^{* *}$ \\
\hline Cumulative sufentanil dose ( $\mu \mathrm{g} / \mathrm{kg})$ & $88.60(20.21-918.52)$ & $21.71(4.50-162.29)^{* *}$ \\
\hline Cumulative MDZ dose ( $\mathrm{mg} / \mathrm{kg}$ ) & $18.22(6.93-51.25)$ & $9.94(2.12-49.83)^{*}$ \\
\hline Duration of sufentanil perf. (h) & $327(136-885)$ & $92(22-211)^{* *}$ \\
\hline Duration of MDZ perf. (h) & $141(2-625)$ & $88(7-232)^{*}$ \\
\hline Sufentanil dose $(\mu \mathrm{g} / \mathrm{kg} / \mathrm{h})$ & $0.33(0.10-1.18)$ & $0.23(0.70-1.96)$ \\
\hline MDZ dose $(\mathrm{mg} / \mathrm{kg} / \mathrm{h})$ & $0.105(0.06-0.35)$ & $0.12(0.05-0.24)$ \\
\hline
\end{tabular}

Significantly higher median cumulative doses of both sufentanil and midazolam were received by WS patients, both in the overall population as well as in the neonate and children subgroups. Median sufentanil cumulative doses in neonates with and without WS were $81.58 \mu \mathrm{g} / \mathrm{kg} / \mathrm{h} \quad(33.83-208.40) \quad$ and $\quad 20.55 \mu \mathrm{g} / \mathrm{kg} / \mathrm{h}$ (5.10-162.29); $P<0.01$, respectively. The respective values for children were $95.61 \mu \mathrm{g} / \mathrm{kg} / \mathrm{h}(20.21-918.52)$ and $34.20 \mu \mathrm{g} / \mathrm{kg} / \mathrm{h}$ (4.50 - 91.69); $P<0.05$. Similar pattern was noted for median midazolam cumulative doses $20.38 \mathrm{mg} / \mathrm{kg} / \mathrm{h} \quad(10.63-51.25)$ and $10.57 \mathrm{mg} / \mathrm{kg} / \mathrm{h}$ $(2.12-49.83) ; P<0.05$ in WS and non-WS groups, respectively. The respective values for children were $16.73 \mathrm{mg} / \mathrm{kg} / \mathrm{h} \quad(6.93-41.36)$ and $9.40 \mathrm{mg} / \mathrm{kg} / \mathrm{h}$ $(2.83-35.45) ; P=0.13$.

Duration of therapy was also higher with WS compared with non-WS group. Median sufentanil treatment duration in neonates in WS and non-WS patients was $378 \mathrm{~h}(177-790)$ and $88.5 \mathrm{~h}(0-211)$;
$P<0.01$, respectively, while the median midazolam treatment duration was $184 \mathrm{~h}(105-625)$ and $82 \mathrm{~h}$ (7 - 219); $P<0.01$, respectively. The respective values for the children groups were $234 \mathrm{~h}(136-885)$ and $142 \mathrm{~h}$ (22 - 184); $P<0.01$ for sufentanil and 113.5 h $(2-398)$ and $111 \mathrm{~h}(24-232) ; P<0.45$ for midazolam. The multivariate analysis showed that the duration of sufentanil treatment gave the best explanation of development of withdrawal syndrome $(0.81$ sensitivity and 0.94 specificity), while the other explanatory variables were not significant. ROC curve analysis was performed on the duration of sufentanil treatment, the AUC was $0.96, P=0.0039$. The cut-off value (risk value) of sufentanil treatment duration for ROC was not a single unambiguous value in case of Youden index, while smallest distance from ROC point with sensitivity and specificity equaled 1 gave the risk value of $177 \mathrm{~h}$ ( 7 days and 9 hours).

No association was found between genotypes 
and WS development.

\section{Discussion}

Our prospective naturalistic study indicated that although the analgosedative therapy was closely monitored using validated scaling systems for both therapeutic efficacy and withdrawal syndrome, achievement of optimal analgosedation is challenging in many patients. Especially the neonate subgroup represented difficult to treat patient population. The COMFORT NEO scale values indicated that in half of the scoring times the neonates were oversedated, while insufficient sedation was rare. On the other hand the sedation in the children subgroup was well maintained since only $7 \%$ of the score values indicated either insufficient sedation or oversedation. The incidence of withdrawal syndrome in both patient groups was high; it was diagnosed in $23 \%$ of neonates and $50 \%$ of children. The neonates received similar hourly doses of both drugs as children, while the treatment duration with sufentanil and sufentanil cumulative dose was lower in the neonate group. This dosing pattern likely explain the different clinical outcome with respect of sedative effect and WS between neonates and children, since the immaturity of the elimination pathways in neonates were likely responsible for the episodes of acute oversedation, when comparable doses were administered to neonates as to the children.

The duration of opioid administration, cumulative dose and number of medications used represented risk factors for the development of withdrawal syndrome. All the subjects, who received sufentanil therapy over 9 days, and, on the contrary, no subject with less than 5.5 days of the sufentanil therapy duration developed WS. Patients with WS also spent significantly longer period on artificial ventilation and in the hospital overall. We followed the symptoms of WS first after 5 days of analgosedation in agreement with previous studies. Previously, the incidence of WS approached $100 \%$ in two studies in patients treated for more than 5 days (Bicudo et al. 1999, Fernandez-Carrion et al. 2013), whereas Franck et al. (2004) reported $86 \%$ incidence. In the other published study by Sfoggia et al. (2013), the global incidence of $34 \%$ for WS was reported, while the incidence in highest drug dose group reached $49 \%$. A recent study suggests that iatrogenic WS after only 3 days of sedation or analgesia may also occur in minority of patients (Da Silva et al. 2016). Our estimate of cut off value of 7 days $(177 \mathrm{~h})$ of sufentanil treatment duration as a risk for development of WS may be considered as rather conservative estimate since we based our observation on relatively strict scoring system of Sophia Observational Scale.

The median sufentanil cumulative doses in our study were approximately 4 times higher in the WS group when compared with the non-WS patients and this difference was similar in neonates and children. The impact of sufentanil cumulative doses on the development of WS has not been studied so far, but since the opioid potency of sufentanil is considered 7-10 times higher in comparison with fentanyl ( $\mathrm{Li}$ et al. 2015), it could be assumed, that the cumulative dose as a risk factor of WS shall be correspondingly lower. Our median values of $95.61 \mu \mathrm{g} / \mathrm{kg}(20.21-918.52)$ and $81.58 \mu \mathrm{g} / \mathrm{kg}$ $(33.83-208.4)$ in the WS group in children and neonates, respectively, compare well with the mean cumulative fentanyl dose $0.98 \mathrm{mg} / \mathrm{kg}$ reported previously in patients with WS (Fernandez-Carrion et al. 2013). Further, Dominguez et al. (2003) found that fentanyl total dose $\geq 0.415 \mathrm{mg} / \mathrm{kg} \quad(415 \mu \mathrm{g} / \mathrm{kg})$ predicted withdrawal with $70 \%$ sensitivity and $78 \%$ specificity. In an earlier study in older children, higher fentanyl cumulative doses, but shorter treatment duration as a risk factor than in our study was reported (Katz et al. 1994). Cumulative fentanyl dose of $1.5 \mathrm{mg} / \mathrm{kg}$ or duration of perfusion for more than 5 days appeared to be a risk for the development of WS, whereas a cumulative fentanyl dose of $>2.5 \mathrm{mg} / \mathrm{kg}(2,500 \mu \mathrm{g} / \mathrm{kg})$ and $>9$ days of therapy was $100 \%$ predictive (Katz et al. 1994). This difference may be probably attributed to different scoring systems used in both studies that may have different sensitivity to detect WS.

Median midazolam cumulative doses in the WS and non-WS groups of $18.22(6.93-51.25)$ and $9.94(2.12-49.83) \mathrm{mg} / \mathrm{kg}$, in our study were within the range of previously reported values. In an early small study, cumulative MDZ dose of $60 \mathrm{mg} / \mathrm{kg}$ was reported to constitute a risk factor for WS (Fonsmark et al. 1999). However, in another study the median of midazolam equivalents per $\mathrm{kg}$ of body weight was $7.6 \mathrm{mg} / \mathrm{kg}$ $(4.2-10.4) v s .2 .3 \mathrm{mg} / \mathrm{kg}(1.0-3.5)$ in patients at risk $v s$. patients at no risk for WS development; $P<0.001$, respectively (Franck et al. 2008). In the SOS evaluation study (concomitant opioid-morphine), the cumulative dose of midazolam was $77.9 \mathrm{mg} / \mathrm{kg}(34.6-169.6)$ with $17(9-27)$ days of exposure in the WS group and $34.8 \mathrm{mg} / \mathrm{kg}(16.9-71.8)$ with 9 days $(6-14)$ of exposure 
in non-WS group $(P<0.0001)$ (Ista et al. 2013). High variability of the midazolam dosing data with respect to WS development is likely to be due to differences in coadministered medications, especially from the analgosedative class, which is largely inconsistent among the published studies.

We have not found any significant association between candidate gene polymorphisms and clinical scoring either for the depth of analgosedation (COMFORT scale) or withdrawal syndrome. The rs 4680 SNP in COMT seems to affect the dosing of study drugs in our patients to achieve equal clinical response. Homozygotes for the variant allele received lower hourly dose than wild-type allele carriers. There are no data on relationship between COMT SNPs and sufentanil efficacy, however, this SNP has been frequently considered in patients treated with other opioids. Variant COMTrs 4680 has shown to be associated with increased pain intensity scores but did not affect morphine or oxycodone consumption in postoperative studies (Kambur et al. 2013, Kolesnikov et al. 2011, Nielsen et al. 2015). In studies focused on chronic pain the variant allele was associated with higher morphine requirements when compared with wild-type homozygous subjects (Rakvag et al. 2005, Reyes-Gibby et al. 2007), but contradictory results have been obtained in other studies (Klepstad et al. 2011, Nielsen et al. 2015, Rakvag et al. 2008, Walter and Lotsch 2009).

We have observed a trend of lower hourly dose of sufentanil in PXR A7635G variant carriers compared to wild-type homozygotes. Experimental data suggest, that PXR activation increases P-glycoprotein (ABCB1) activity in vivo and tightens the blood-brain barrier to methadone, reducing the drug's CNS efficacy (Bauer et al. 2006). In theory, variant PXR with lower activity would alter the pain perception or enable decreased opioid dose.

$A B C B 1$ 3435TT homozygotes in our study population received significantly higher mean hourly midazolam dose compared with wild-type homozygotes. Midazolam belongs among known ABCB1 substrates, but one study did not find association between clinical response to midazolam, midazolam plasma levels and $A B C B 1$ SNPs (Byon et al. 2012, Tolle-Sander et al. 2003).

We acknowledge the basic limitation of our study, which are the rather limited number of patients and the non-interventional study design. It should be, however, emphasized that this is the first study directly focused on sufentanil-induced analgosedation and withdrawal syndrome in critically ill neonates and children and as such the descriptive nature of the study is highly relevant. Moreover, the study adds preliminary data of the pharmacogenetic background for sufentanil and midazolam related clinical effects in pediatric patients, although these need to be further confirmed.

\section{Conclusions}

Cumulative sufentanil and midazolam doses as well as duration of treatment represent risk factors for the development of WS. The sufentanil treatment duration of $177 \mathrm{~h}$ or higher is an independent risk for the development of WS. SNPs in the candidate genes of $C O M T, P X R$ and $A B C B 1$ may affect the dosing of analgosedative drugs, but this needs to be further investigated.

\section{Conflict of Interest}

There is no conflict of interest.

\section{Acknowledgements}

The work was supported by the Charles University SVV-2016-260263 project, by PRVOUKP25/LF1/2 project and by the General University Hospital RV-project (64-165/2012).

\section{References}

AKCAN-ARIKAN A, ZAPPITELLI M, LOFTIS LL, WASHBURN KK, JEFFERSON LS, GOLDSTEIN SL: Modified RIFLE criteria in critically ill children with acute kidney injury. Kidney Int 71: 1028-1035, 2007.

ANDERSON BJ, LARSSON P: A maturation model for midazolam clearance. Paediatr Anaesth 21: 302-308, 2011.

ARNOLD JH, TRUOG RD, ORAV EJ, SCAVONE JM, HERSHENSON MB: Tolerance and dependence in neonates sedated with fentanyl during extracorporeal membrane oxygenation. Anesthesiology 73: 1136-1140, 1990.

BARTOSOVA O, POLANECKY O, PERLIK F, ADAMEK S, SLANAR O: OPRM1 and ABCB1 polymorphisms and their effect on postoperative pain relief with piritramide. Physiol Res 64 (Suppl. 4): S521-S527, 2015. 
BAUER B, YANG X, HARTZ AM, OLSON ER, ZHAO R, KALVASS JC, POLLACK GM, MILLER DS: In vivo activation of human pregnane $\mathrm{X}$ receptor tightens the blood-brain barrier to methadone through $\mathrm{P}$-glycoprotein up-regulation. Mol Pharmacol 70: 1212-1219, 2006.

BICUDO JN, DE SOUZA N, MANGIA CM, DE CARVALHO WB: [Withdrawal syndrome associated with cessation of fentanyl and midazolam in pediatrics]. Rev Assoc Med Bras 45: 15-18, 1999.

BUZKOVA H, PECHANDOVA K, SLANAR O, PERLIK F: Frequency of single nucleotide polymorphisms of CYP2D6 in the Czech population. Cell Biochem Funct 26: 76-81, 2008.

BYON HJ, PARK KS, PARK YH, KIM JT, JUNG CW, KIM HS: The influence of DNA polymorphism of multidrug resistant 1 (MDR1) on the effect of midazolam pretreatment in children. Korean J Anesthesiol 62: 332-336, 2012.

DA SILVA PS, REIS ME, FONSECA TS, FONSECA MC: Opioid and benzodiazepine withdrawal syndrome in PICU patients: which risk factors matter? J Addict Med 10: 108-114, 2016.

DE JONGE H, ELENS L, DE LOOR H, VAN SCHAIK RH, KUYPERS DR: The CYP3A4*22 C>T single nucleotide polymorphism is associated with reduced midazolam and tacrolimus clearance in stable renal allograft recipients. Pharmacogenomics J 15: 144-152, 2015.

DOMINGUEZ KD, LOMAKO DM, KATZ RW, KELLY HW: Opioid withdrawal in critically ill neonates. Ann Pharmacother 37: 473-477, 2003.

FERNANDEZ-CARRION F, GABOLI M, GONZALEZ-CELADOR R, GOMEZ DE QUERO-MASIA P, FERNANDEZ-DE MIGUEL S, MURGA-HERRERA V, SERRANO-AYESTARAN O, SANCHEZGRANADOS JM, PAYO-PEREZ R: Withdrawal syndrome in the pediatric intensive care unit. incidence and risk factors. Med. Intensiva 37: 67-74, 2013.

FONSMARK L, RASMUSSEN YH, CARL P: Occurrence of withdrawal in critically ill sedated children. Crit Care Med 27: 196-199, 1999.

FRANCK LS, NAUGHTON I, WINTER I: Opioid and benzodiazepine withdrawal symptoms in paediatric intensive care patients. Intensive Crit Care Nurs 20: 344-351, 2004.

FRANCK LS, HARRIS SK, SOETENGA DJ, AMLING JK, CURLEY MA: The Withdrawal Assessment Tool-1 (WAT-1): an assessment instrument for monitoring opioid and benzodiazepine withdrawal symptoms in pediatric patients. Pediatr Crit Care Med 9: 573-580, 2008.

FRENCH JP, NOCERA M: Drug withdrawal symptoms in children after continuous infusions of fentanyl. $J$ Pediatr Nurs 9: 107-113, 1994.

GEORGE SZ, WALLACE MR, WRIGHT TW, MOSER MW, GREENFIELD WH 3RD, SACK BK, HERBSTMAN DM, FILLINGIM RB: Evidence for a biopsychosocial influence on shoulder pain: pain catastrophizing and catechol-O-methyltransferase (COMT) diplotype predict clinical pain ratings. Pain 136: 53-61, 2008.

GOLDSTEIN B, GIROIR B, RANDOLPH A, INTERNATIONAL CONSENSUS CONFERENCE ON PEDIATRIC SEPSIS. International pediatric sepsis consensus conference: definitions for sepsis and organ dysfunction in pediatrics. Pediatr Crit Care Med 6: 2-8, 2005.

GRANT MJ, BALAS MC, CURLEY MA, TEAM RI: Defining sedation-related adverse events in the pediatric intensive care unit. Heart Lung 42: 171-176, 2013.

CHEN J, LIPSKA BK, HALIM N, MA QD, MATSUMOTO M, MELHEM S, KOLACHANA BS, HYDE TM, HERMAN MM, APUD J, EGAN MF, KLEINMAN JE, WEINBERGER DR: Functional analysis of genetic variation in catechol-O-methyltransferase (COMT): effects on mRNA, protein, and enzyme activity in postmortem human brain. Am J Hum Genet 75: 807-821, 2004.

ISTA E, DE HOOG M, TIBBOEL D, VAN DIJK M: Implementation of standard sedation management in paediatric intensive care: effective and feasible? J Clin Nurs 18: 2511-2520, 2009.

ISTA E, VAN DIJK M, DE HOOG M, TIBBOEL D, DUIVENVOORDEN HJ: Construction of the Sophia Observation withdrawal Symptoms-scale (SOS) for critically ill children. Intensive Care Med 35: 1075-1081, 2009.

ISTA E, DE HOOG M, TIBBOEL D, DUIVENVOORDEN HJ, VAN DIJK M: Psychometric evaluation of the Sophia Observation withdrawal symptoms scale in critically ill children. Pediatr Crit Care Med 14: 761-769, 2013. 
KAMBUR O, KAUNISTO MA, TIKKANEN E, LEAL SM, RIPATTI S, KALSO EA: Effect of catechol-omethyltransferase-gene (COMT) variants on experimental and acute postoperative pain in 1,000 women undergoing surgery for breast cancer. Anesthesiology 119: 1422-1433, 2013.

KATZ R, KELLY HW, HSI A: Prospective study on the occurrence of withdrawal in critically ill children who receive fentanyl by continuous infusion. Crit Care Med 22: 763-767, 1994.

KLEPSTAD P, FLADVAD T, SKORPEN F, BJORDAL K, CARACENI A, DALE O, DAVIES A, KLOKE M, LUNDSTROM S, MALTONI M, ET AL.: Influence from genetic variability on opioid use for cancer pain: a European genetic association study of 2294 cancer pain patients. Pain 152: 1139-1145, 2011.

KOLESNIKOV Y, GABOVITS B, LEVIN A, VOIKO E, VESKE A: Combined catechol-O-methyltransferase and mu-opioid receptor gene polymorphisms affect morphine postoperative analgesia and central side effects. Anesth Analg 112: 448-453, 2011.

LACHMAN HM, PAPOLOS DF, SAITO T, YU YM, SZUMLANSKI CL, WEINSHILBOUM RM: Human catecholO-methyltransferase pharmacogenetics: description of a functional polymorphism and its potential application to neuropsychiatric disorders. Pharmacogenetics 6: 243-250, 1996.

LI B, WANG H, GAO C: Bupivacaine in combination with fentanyl or sufentanil in epidural/intrathecal analgesia for labor: a meta-analysis. J Clin Pharmacol 55: 584-591, 2015.

MAMIE C, REBSAMEN MC, MORRIS MA, MORABIA A: First evidence of a polygenic susceptibility to pain in a pediatric cohort. Anesth Analg 116: 170-177, 2013.

NIELSEN LM, OLESEN AE, BRANFORD R, CHRISTRUP LL, SATO H, DREWES AM: Association between human pain-related genotypes and variability in opioid analgesia: an updated review. Pain Pract 15: 580-594, 2015.

OERTEL BG, KETTNER M, SCHOLICH K, RENNE C, ROSKAM B, GEISSLINGER G, SCHMIDT PH, LOTSCH J: A common human micro-opioid receptor genetic variant diminishes the receptor signaling efficacy in brain regions processing the sensory information of pain. J Biol Chem 284: 6530-6535, 2009.

OLESON L, VON MOLTKE LL, GREENBLATT DJ, COURT MH: Identification of polymorphisms in the 3'-untranslated region of the human pregnane $\mathrm{X}$ receptor (PXR) gene associated with variability in cytochrome P450 3A (CYP3A) metabolism. Xenobiotica 40: 146-162, 2010.

PECHANDOVA K, BUZKOVA H, SLANAR O, PERLIK F: Polymorphisms of the MDR1 gene in the Czech population. Folia Biol (Praha) 52: 184-189, 2006.

POH YN, POH PF, BUANG SN, LEE JH: Sedation guidelines, protocols, and algorithms in PICUs: a systematic review. Pediatr Crit Care Med 15: 885-892, 2014.

POKORNÁ P, POSCH L, BAŠKOVÁ M., VOBRUBA V, TIBBOEL D: Pharmacodynamics parameters determine analgesic and sedative drug dosing during neonatal and pediatric extracorporeal membrane oxygenation. J J Pharma Pharmacovigilance 2: 008, 2016.

POLÍVKOVÁ K: Polymorfismy genu PXR v české populaci. In: Diploma Thesis, 2006.

RAKVAG TT, ROSS JR, SATO H, SKORPEN F, KAASA S, KLEPSTAD P: Genetic variation in the catechol-Omethyltransferase (COMT) gene and morphine requirements in cancer patients with pain. Mol Pain 4: 64, 2008.

RAKVAG TT, KLEPSTAD P, BAAR C, KVAM TM, DALE O, KAASA S, KROKAN HE, SKORPEN F: The Val158Met polymorphism of the human catechol-O-methyltransferase (COMT) gene may influence morphine requirements in cancer pain patients. Pain 116: 73-78, 2005.

REDDEN DT, SHIELDS PG, EPSTEIN L, WILEYTO EP, ZAKHARKIN SO, ALLISON DB, LERMAN C: CatecholO-methyl-transferase functional polymorphism and nicotine dependence: an evaluation of nonreplicated results. Cancer Epidemiol Biomarkers Prev 14: 1384-1389, 2005.

REYES-GIBBY CC, SHETE S, RAKVAG T, BHAT SV, SKORPEN F, BRUERA E, KAASA S, KLEPSTAD P: Exploring joint effects of genes and the clinical efficacy of morphine for cancer pain: OPRM1 and COMT gene. Pain 130: 25-30, 2007.

SENG KY, HEE KH, SOON GH, SAPARI NS, SOONG R, GOH BC, LEE LS: CYP3A5*3 and bilirubin predict midazolam population pharmacokinetics in Asian cancer patients. J Clin Pharmacol 54: 215-224, 2014. 
SFOGGIA A, FONTELA PS, MORAES A, DA SILVA F, SOBER RB, NOER RB, BRUNO F, EINLOFT P, GARCIA PC, PIVA JP: [Sedation and analgesia in children submitted to mechanical ventilation could be overestimated?] J Pediatr (Rio J) 79: 343-348, 2003.

SHIH PS, HUANG JD: Pharmacokinetics of midazolam and 1'-hydroxymidazolam in Chinese with different CYP3A5 genotypes. Drug Metab Dispos 30: 1491-1496, 2002.

SCHUG SA, ZECH D, GROND S: Adverse effects of systemic opioid analgesics. Drug Saf 7: 200-213, 1992.

TOLLE-SANDER S, RAUTIO J, WRING S, POLLI JW, POLLI JE: Midazolam exhibits characteristics of a highly permeable P-glycoprotein substrate. Pharm Res 20: 757-764, 2003.

VAN DIJK M, DE BOER JB, KOOT HM, TIBBOEL D, PASSCHIER J, DUIVENVOORDEN HJ: The reliability and validity of the COMFORT scale as a postoperative pain instrument in 0 to 3 -year-old infants. Pain 84: 367-377, 2000.

VAN DIJK M, ROOFTHOOFT DW, ANAND KJ, GULDEMOND F, DE GRAAF J, SIMONS S, DE JAGER Y, VAN GOUDOEVER JB, TIBBOEL D: Taking up the challenge of measuring prolonged pain in (premature) neonates: the COMFORTneo scale seems promising. Clin J Pain 25: 607-616, 2009.

VAN SCHAIK RH, VAN DER HEIDEN IP, VAN DEN ANKER JN, LINDEMANS J: CYP3A5 variant allele frequencies in Dutch Caucasians. Clin Chem 48: 1668-1671, 2002.

WACHMAN EM, HAYES MJ, BROWN MS, PAUL J, HARVEY-WILKES K, TERRIN N, HUGGINS GS, ARANDA JV, DAVIS JM: Association of OPRM1 and COMT single-nucleotide polymorphisms with hospital length of stay and treatment of neonatal abstinence syndrome. JAMA 309: 1821-1827, 2013.

WALTER C, LOTSCH J: Meta-analysis of the relevance of the OPRM1 118A $>$ G genetic variant for pain treatment. Pain 146: 270-275, 2009.

WONG M, BALLEINE RL, COLLINS M, LIDDLE C, CLARKE CL, GURNEY H: CYP3A5 genotype and midazolam clearance in Australian patients receiving chemotherapy. Clin Pharmacol Ther 75: 529-538, 2004.

ZUBIETA JK, HEITZEG MM, SMITH YR, BUELLER JA, XU K, XU Y, KOEPPE RA, STOHLER CS, GOLDMAN D: COMT val158met genotype affects mu-opioid neurotransmitter responses to a pain stressor. Science 299: 1240-1243, 2003. 